\title{
SYCP1 Gene
}

National Cancer Institute

\section{Source}

National Cancer Institute. SYCP1 Gene. NCI Thesaurus. Code C114398.

This gene plays a role in meiotic prophase. 